\title{
MYXOZYMA NIPPONENSIS SP. NOV. (CANDIDACEAE), A NEW SPECIES RECOVERED FROM FRASS OF IPS TYPOGRAPHUS F. JAPONICUS NIIJIMA
}

\author{
FRANS SPAAIJ, ${ }^{*}$ GABRIELE WEBER, TAKAYUKI AOKI, \\ AND JOHANNES PETRUS VAN DER WALT ${ }^{2}$ \\ Lehrstuhl für Spezielle Botanik/Mykologie, Universität Tübingen, \\ 72076 Tübingen, Germany \\ ${ }^{1}$ National Institute of Agrobiological Resources, Tsukuba 305, Japan \\ ${ }^{2}$ Department of Microbiology and Biochemistry, University of the Orange Free State, \\ Bloemfontein 9300, South Africa
}

(Received September 1, 1992)

\begin{abstract}
Two strains of an undescribed species belonging to the anamorphic genus Myxozyma were recovered from frass of a Ips typographus f. japonicus larvae. The strains differ from the accepted species of the genus in their utilization of carbon sources, mol\% $\mathrm{G}+\mathrm{C}$ and low percentage of DNA-DNA homology. A description of the new species Myxozyma nipponensis is given and a key to the genus is provided.
\end{abstract}

The geographical distribution of species belonging to the genus Myxozyma van der Walt et al. (18) is known from South Africa, U.S.A., Mexico, Australia and Costa Rica (11). The recent recovering of a new species from Germany and an unpublished record of Myxozyma geophila van der Walt et al. (16) from Japan (van der Walt pers. com.) suggests that the geographical distribution of the species belonging to the genus Myxozyma is world-wide. Given the unexpected record of M. geophila in Japanese soils, it was decided to extend the study of the occurrence of lipomycetous anamorphs in other habitats in Japan. During this study a hitherto undescribed species was recovered from frass of a larvae of Ips typographus $\mathrm{f}$. japonicus.

\section{MATERIALS AND METHODS}

The strains were examined for their morphological, cultural and physiological properties according to the standard methods adopted for yeast identification (17). The utilization of carbon and nitrogen sources was examined at $25^{\circ} \mathrm{C}$ on a rotary

* Address reprint requests to: Dr. F. Spaaij, Lehrstuhl für Spezielle Botanik/Mykologie, Universität Tübingen, Auf der Morgenstelle 1, 72076 Tübingen, Germany. 
shaker rotating at a speed of $100 \mathrm{rpm}$. The utilization of nitrogen sources was reconfirmed by the auxanographic technique. For the determination of the DNA base composition, cells were grown in $2 \% \mathrm{GYP}(17)$ at $25^{\circ} \mathrm{C}$ on a rotary shaker until the late log phase. The extraction and purification of the DNA were performed by a combination of the methods described by Maniatis et al. (5) and Cryer et al. (2). The purity of the DNA preparation was checked by the photometric method as recommended by Maniatis et al. (5).

The base composition of the DNA was determined in $0.1 \mathrm{SSC}(\mathrm{SSC}=0.15 \mathrm{M}$ sodium chloride and $0.015 \mathrm{M}$ sodium citrate $\mathrm{pH} 7.0$ ) from the thermal denaturation profile according to the method of Owen et al. (7) with a Gilford Response UV-VIS Spectrophotometer with Thermal Programming software, at a heating rate of $0.1^{\circ} \mathrm{C}$ per min. The composition was calculated by the formula mol\% $\mathrm{G}+\mathrm{C}=2.08 \times T_{\mathrm{m}}$ -106.4. As a control a standard preparation of DNA of Candida parapsilosis CBS $604\left(T_{\mathrm{m}} 70.6^{\circ} \mathrm{C}\right)$ was included in every determination. The value reported reflects the mean and standard deviation of three determinations. The extent of DNADNA reassociation was determined using the same instrument following the procedures described by Seidler and Mandel (9) as modified by Kurtzman et al. (4). Ubiquinone isoprenologues were extracted and purified as described by Yamada and Kondô $(20,21)$. For the determination of the type of Co-Q, reverse-phase thin-layer chromatography was employed, using Merck HPTLC RP$18 \mathrm{~F} 254 \mathrm{~s}$ plates and a mixture of acetone : acetonitrile $(80: 20, \mathrm{v} / \mathrm{v})$ as the developing solvent (6). The separated components were detected under ultraviolet light at $254 \mathrm{~nm}$.

Observations by TEM were based on material grown on GYP agar at $25^{\circ} \mathrm{C}$ for five days and fixed in $2 \%$ glutaraldehyde in $0.1 \mathrm{M}$ cacodylate buffer $\left(\mathrm{pH} \mathrm{7.2)}\right.$ at $4^{\circ} \mathrm{C}$ for $12 \mathrm{~h}$. After fixation the cells were washed in $0.1 \mathrm{M}$ cacodylate buffer and postfixed in $1 \% \mathrm{OsO}_{4}$ in the same buffer for $2 \mathrm{~h}$ in the dark. After 5 washes in distilled water, the material was dehydrated in acetone using the following series: $25,50,70,95$ and $3 \times 100 \%, 15 \mathrm{~min}$ at each step. The cells were flat-embedded in resin (14) as described by Bauer and Oberwinkler (1). Serial section (35-55 nm) were cut and poststained with lead citrate $(8)$ for $5 \mathrm{~min}$ at room temperature and washed with distilled water. The sections were examined with a Zeiss EM 108 transmission electron microscope at $80 \mathrm{kV}$.

RESULTS

\section{Description}

Myxozyma nipponensis Spaaij et Weber sp. nov.

In extracto malti post triduum $25^{\circ} \mathrm{C}$ cellulae globosae ovoideae ellipsoideaeque 2.0-9.0 $\times 2.0-9.0 \mu \mathrm{m}$ gemmatae holobastice incapsulatae singulae vel binae. Post hebdomades 4 temperatura ambuente, sedimentum et annulus inchoatus adsunt. In agaro malti triduum $25^{\circ} \mathrm{C}$ formae et dimensiones cellularum eaedum sunt quae in 
extracto malti. Cultura post hebdornanes 4 temperatura ambuente viscosa glabra nitida; margine glabro. In agaro farinae Zeae maydis confecto post decemduum $25^{\circ} \mathrm{C}$ pseudohyphae et hyphae nullae. Fermentatio gaseosa nulla. D-galactoso L-sorboso D-riboso (lente) D-xyloso L-arabinoso D-arabinoso L-rhamnoso $\alpha$ - $\alpha$ trehaloso cellobioso(lente) salicino(lente) glycerolo $m$-erythritolo(lente) ribitolo (lente) xylitolo L-arabinitolo(lente) D-glucitolo D-mannitolo(lente) myo-inositolo (lente) D-glucono-1,5-lactono(lente) D-glucuronato(lente) succinato citrato(lente) ethylamino hydrochlorico L-lysino(lente) cadaverino dihydrochlorico creatino creatinino imidazolo utitur neque D-glucosamino sucroso maltoso methyl- $\alpha$-Dglucosamino melibioso lactoso raffinoso melezitoso inulino amylo galactitolo 2keto-gluconato 5-keto-gluconato D-gluconato D-galacturonato DL-lactato methanolo ethanolo nitrato nec nitrito. Crescit coram parte una cycloheximidi per mille. Vitaminae externae ad crescentıam necessariae sunt. Materia amyloidea formatur. Ureum exigue finditur. Crescere non potest in $37^{\circ} \mathrm{C}$ sed. Systema coenzymatis Q9. $\mathrm{G}+\mathrm{C}$ acidi deoxyribonucleati $48.9 \pm 0.4 \mathrm{~mol}$ per centum.

Growth in malt extract: After 3 days at $25^{\circ} \mathrm{C}$, the cells are globose to ovoid, 2.0-9.0 $\times 2.0-9.0 \mu \mathrm{m}$, encapsulated, reproducing by holoblastic budding (Fig. 1), occurring singly or aggregated. After four weeks at ambient temperature a sediment and an incomplete ring are formed.

Growth on malt extract agar: After three days at $25^{\circ} \mathrm{C}$ the cells are of the same form and dimensions as in malt extract. After four weeks the streak culture is viscous to mucoid, crearn-colored, partly hyaline, smooth and glistening with an entire margin.

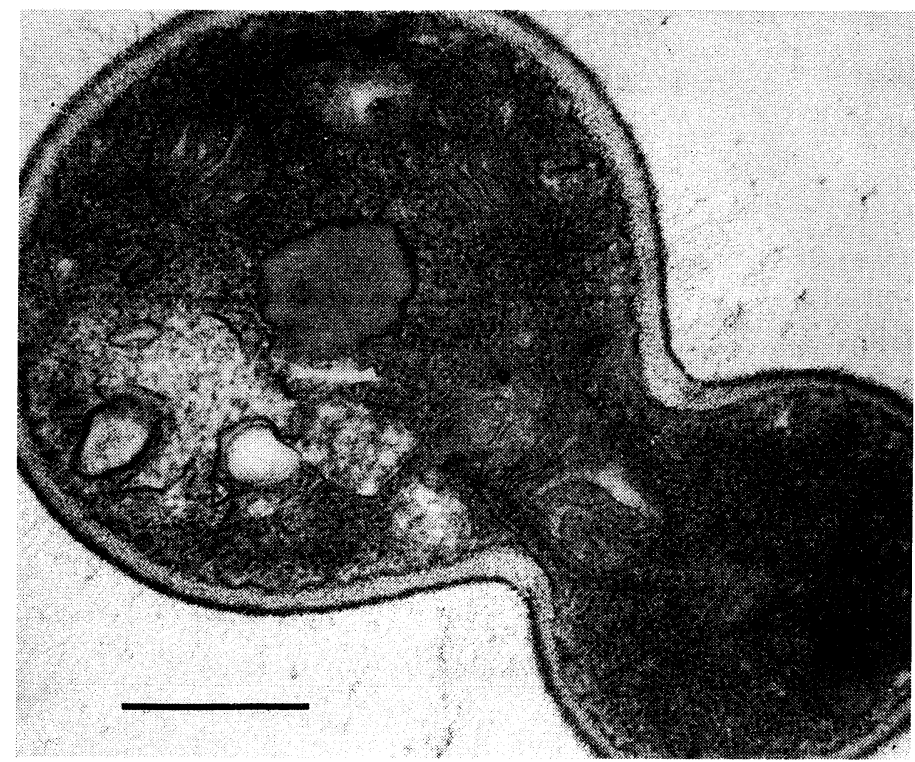

Fig. 1. Myxozyma nipponensis.

TEM micrograph showing holoblastic budding. Insert ber represents $0.5 \mu \mathrm{m}$. 
Dalmau plate cultures on corn meal agar: After ten days at $25^{\circ} \mathrm{C}$ neither pseudohyphae nor hyphae are formed.

Formation of ascospores: Not observed.

Fermentation: No visible gas formation from glucose.

Splitting of arbutin: Positive (delayed).

Growth in vitamin-free medium: Absent.

Growth at $37^{\circ} \mathrm{C}$ : Absent

Formation of amyloid meterial: Positive, coloring blue-green with iodine.

Growth in the presence of $0.1 \%$ cycloheximide: Positive.

Growth on $50 \%(\mathrm{~m} / \mathrm{m})$ glucose-yeast extract agar: Absent.

Hydrolysis of urea: Very weak.

Color reaction with Diazonium Blue B: Absent.

Mol\% G + C: 48.9 \pm 0.4 .

Major coenzyme Q system: Q9.

Utilization of carbon sources:

$\begin{array}{llllll}\text { D-Galactose } & + & \text { Melibiose } & - & \text { myo-Inositol } & \text { + D } \\ \text { L-Sorbose } & + & \text { Lactose } & - & \text { D-Glucono-1,5-lactone } & +\mathrm{D} \\ \text { D-Glucosamine } & - & \text { Raffinose } & - & \text { 2-Keto-D-gluconate } & - \\ \text { D-Ribose } & + \text { D } & \text { Melezitose } & - & \text { 5-Keto-D-gluconate } & - \\ \text { D-Xylose } & + & \text { Inulin } & - & \text { D-Gluconate } & - \\ \text { L-Arabinose } & + & \text { Starch } & - & \text { D-Glucuronate } & +\mathrm{D} \\ \text { D-Arabinose } & + & \text { Glycerol } & + & \text { D-Galacturonate } & - \\ \text { L-Rhamnose } & + & \text { m-Erythritol } & + & \text { DL-Lactate } & - \\ \text { Sucrose } & - & \text { Ribitol } & +\mathrm{D} & \text { Succinate } & + \\ \text { Maltose } & - & \text { Xylitol } & + & \text { Citrate } & +\mathrm{D} \\ \alpha, \alpha \text {-Trehalose } & + & \text { L-Arabinitol } & +\mathrm{D} & \text { Methanol } & - \\ \text { Me- } \alpha \text {-D-glucoside } & - & \text { D-Glucitol } & + & \text { Ethanol } & - \\ \text { Cellobiose } & +\mathrm{D} & \text { D-Mannitol } & +\mathrm{D} & & \\ \text { Salicin } & +\mathrm{D} & \text { Galactitol } & - & & \end{array}$

Utilization of nitrogen sources:

Potassium nitrate

- Cadaverine dihydrochloride

Sodium nitrite

- Creatine

Ethylamine hydrochloride

$+$

Creatinine

L-Lysine

+ Imidazole

$\mathrm{D}$

$+\mathrm{D}$

$+\mathrm{D}$

$+\mathrm{D}$

$-$

Table 1. Extent of DNA complementarity among Myxozyma nipponensis, Myxozyma melibiosi, Myxozyma sirexii and Myxozyma udenii.

\begin{tabular}{ccccc}
\hline \multirow{2}{*}{ Strain } & \multicolumn{4}{c}{$\%$ DNA $^{a}$ reassociation with } \\
\cline { 2 - 5 } & $\begin{array}{c}\text { M. nipponensis } \\
\text { FS-HL-314 }\end{array}$ & $\begin{array}{c}\text { M. melibiosi } \\
\text { CBS } 7219\end{array}$ & $\begin{array}{c}\text { M. sirexii } \\
\text { FS-HL-270 }\end{array}$ & $\begin{array}{c}\text { M. udenii } \\
\text { CBS 7439 }\end{array}$ \\
\hline M. nipponensis & 100 & 20 & 19 & 28 \\
\hline
\end{tabular}

\footnotetext{
${ }^{a}$ Standard deviation $\leq \mathbf{5}$ determined from three determinations.
} 
Origin of strains studied: The morphological and physiological characters listed for Myxozyma nipponensis are based on the study of two strains recovered from frass of a larvae of the bark beetle Ips typographus f. japonicus. The frass was collected on 4th October 1990 from Picea yezoensis in Furano-shi, Hokkaido, Japan by Dr. Y. Yamaoka and Dr. T. Takahashi. The non-living holotype has been deposited as Specimen FS-HL-314 in the Bayrische Staatssammlung in München, Germany.

\section{DISCUSSION}

Since the strains studied are distinguished by hyaline, encapsulated, multilateral budding cells, a characteristic ascomycetous cell-wall ultrastructure, mucoid to glutinous colonies, the production of extracellular amyloid material coloring bluegreen with iodine, a strictly oxidative metabolism, and the utilization of imidazole as sole source of nitrogen, they possess the characters which discriminate the species of Myxozyma from those accepted in the anamorphic genera Candida Berkhout and Cryptococcus Kützing. The combination of these characters together with the absence of ascospore formation and the detected coenzyme Q9 indicate that the new species should be assigned to the genus Myxozyma.

The characters which distinguish $M$. nipponensis from other accepted species within the genus are listed in Table 2.

Beside the differences in the utilization of various carbon sources, the detected mol\% $\mathrm{G}+\mathrm{C}$ of the DNA discriminates $\boldsymbol{M}$. nipponensis from $\boldsymbol{M}$. geophila, $\boldsymbol{M}$. kluyveri, M. lipomycoides, M. mucilagina, M. neotropica and $M$. vanderwaltii. Although the difference in the $\mathrm{mol} \% \mathrm{G}+\mathrm{C}$ of $\boldsymbol{M}$. nipponensis, $\boldsymbol{M}$. melibiosi, $\boldsymbol{M}$. sirexii and $M$. udenii fell within a range of $2 \%$, the low extent of DNA-DNA reassociation (Table 1) and the fact that ascospore formation could not be induced in mixed cultures of these four species, indicate that these taxa are genetically distinct and representative separate biological species.

Kurtzman and Liu (3) studied the evolutionary affinities of species assigned to the genus Myxozyma from ribosomal sequence divergence. From their results they concluded that $M$. mucilagina, M. melibiosi, and M. geophila are closely related whereas $M$. lipomycoides had an isolated position from these species. Although not that isolated in terms of its ribosomal sequence divergence, $M$. lipomycoides remains singular by its unique isoenzyme pattern (19), and the Co Q9 system. In terms of the latter character, $M$. lipomycoides shows agreement with $M$. nipponensis. The extent to which these two ecologically distinct species are related, remains to be assessed by comparison of their isoenzyme patterns and ribosomal sequence divergence.

The ten described species of the genus Myxozyma may be distinguished by the following: 


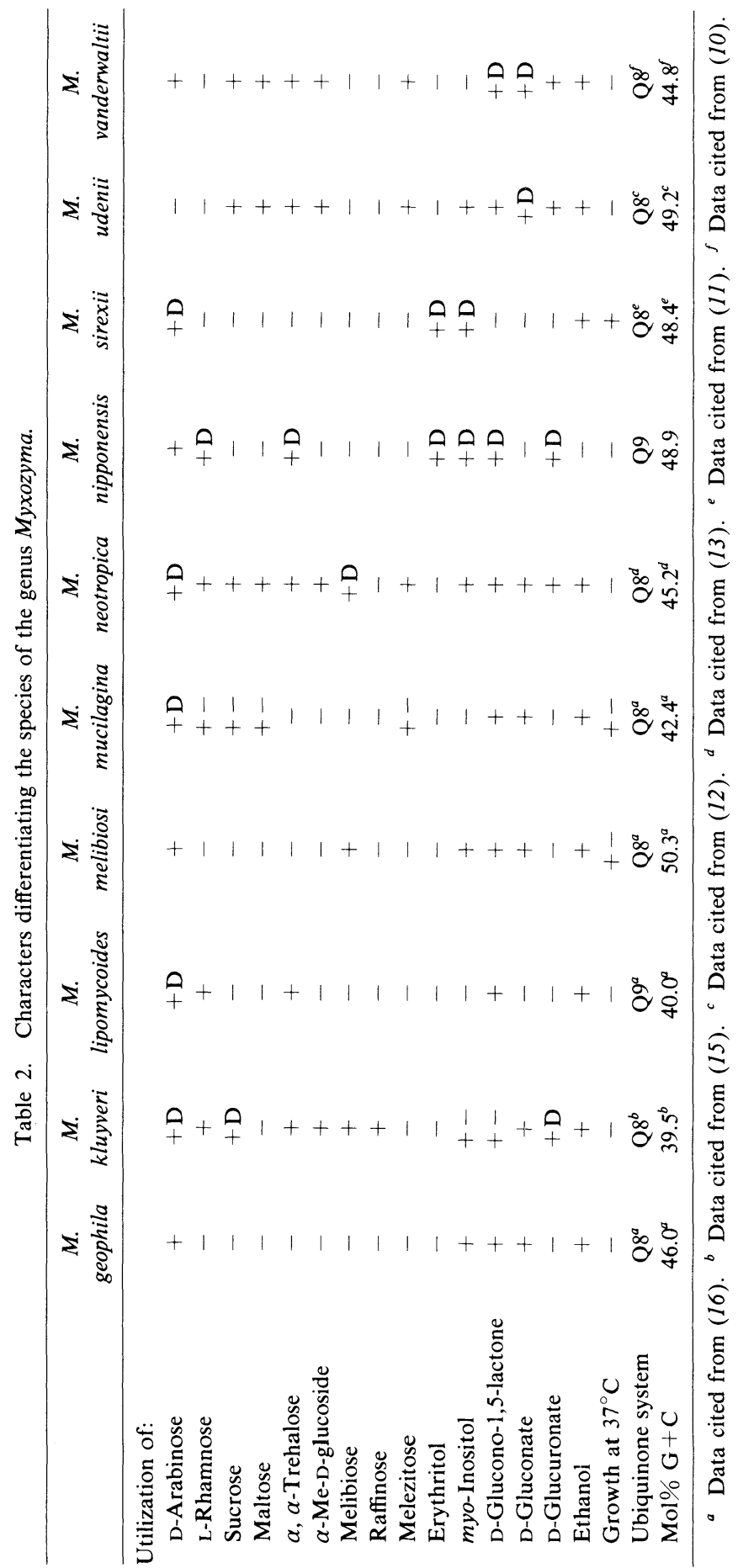


Key to the genus Myxozyma:

1. Raffinose utilized

M. kluyveri

Raffinose not utilized

2. Melezitose utilized

Melezitose not utilized

3. $\alpha$ - $\alpha$-Trehalose utilized

$\alpha-\alpha$-Trehalose not utilized

M. mucilagina

4. D-Arabinose utilized

D-Arabinose not utilized

M. udenii

5. L-Rhamnose utilized

6

L-Rharnnose not utilized

M. vanderwaltii

6. Sucrose utilized

M. neotropica

Sucrose not utilized

M. nipponensis

7. myo-Inositol utilized

myo-Inositol not utilized

8. D-Glucono-1,5-lactone utilized

9

D-Glucono-1,5-lactone not utilized

M. sirexii

9. Melibiose utilized

M. melibiosi

Melibiose not utilized

M. geophila

10. $\alpha$ - $\alpha$-Trehalose utilized $\alpha-\alpha$-Trehalose not utilized

We thank Miss K. Stögerer for skillful technical assistance and Miss S. Silberhorn and Dr. R. Bauer for assistance with the TEM.

\section{REFERENCES}

1) Bauer, R. and Oberwinkler, F., Nuclear degeneration during ballistospore formation of Cronartium asclepiadeum (Uredinales). Bot. Acta, 101, 272-282 (1988).

2) Cryer, D. R., Eccleshall, R., and Marmur, J., Isolation of yeast DNA. In Methods of Cell Biology, Vol. XII, ed. by Prescott, D. M., Academic Press, New York/San Francisco/London (1975), p. 3944.

3) Kurtzman, C. P. and Liu, Z., Evolutionary affinities of species assigned to Lipomyces and Myxozyrna estimated from ribosomal RNA sequence divergence. Curr. Microbiol., 21, 387-393 (1990).

4) Kurtzman, C. P., Smiley, J. M., Johnson, C. J., Wickerham, L. J., and Fuson, G. B., Two closely related and heterothallic species, Pichia amylophila and Pichia mississipiensis: Characterization by hybridisation and deoxyribonucleic acid reassociation. Int. J. Syst. Bacteriol., 30, 208-216 (1980).

5) Maniatis, T., Fritsch, E. F., and Sambrook, J., Molecular Cloning, a Laboratory Guide, Cold Spring Harbor, New York (1982).

6) Nakase, T. and Suzuki, M., Taxonomic studies on Debaryomyces hansenii (Zopf) Lodder et Kreger-van Rij and related species. I. Chemotaxonomic investigations. J. Gen. Appl. Microbiol., 31, 49-69 (1985). 
7) Owen, R. J., Hill, L. R., and Lapage, S. P., Determination of DNA base compositions from melting profiles in dilute buffers. Biopolymers, 7, 503-516 (1969).

8) Reynolds, E. S., The use of lead citrate at high $\mathrm{pH}$ as an electron opaque stain in electron microscopy. J. Cell Biol., 17, 208-212 (1963).

9) Seidler, R. J. and Mandel, M., Quantitative aspects of deoxyribonucleic acid renaturation: Base composition, site of chromosome replication and polynucleotide homologies. J. Bacteriol., 106, 608-614 (1971).

10) Spaaij, F., Weber, G., and Smith Th., M., Myxozyma vanderwaltii (Candidaceae), a new yeast species isolated from a flower of Protea repens (L.) L. Antonie van Leeuwenhoek, 63, 17-21 (1993).

11) Spaaij, F., Weber, G., and Walt van der, J. P., Myxozyma sirexii sp. nov. (Candidaceae), a new yeast isolated from frass of the woodwasp Sirex juvencus. L. Syst. Appl. Microbiol., 15, 427-431 (1992).

12) Spaaij, F., Weber, G., Walt van der, J. P., and Oberwinkler, F., Myxozyma udenii a new yeast isolated from the rhizosphere of Mangifera indica. Syst. Appl. Microbiol., 13, 182-185 (1990).

13) Spaaij, F., Weber, G., Walt van der, J. P., and Oberwinkler, F., Myxozyma neotropica sp. nov., a new yeast species from Costa Rica. Antonie van Leeuwenhoek, 62, 261-265 (1992).

14) Spurr, A. R., A low-viscosity epoxy resin embedding medium for electron microscopy. $J$. Ultrastruct. Res., 26, 31-43 (1969).

15) Walt van der, J. P., Spencer-Martins, I., Yamada, Y., and Richards, P. D. G., Myxozyma kluyveri sp. nov. (Candidaceae) - a new species from Southern Africa. Antonie van Leeuwenhoek, 55, 297302 (1989).

16) Walt van der, J. P., Yamada, Y., Nakase, T., and Richards, P. D. G., Myxozyma geophila and Myxozyma lipomycoides spp. nov., two new anamorphic, lipomycetaceous yeasts from Southern Africa. Syst. Appl. Microbiol., 91, 21-124 (1987).

17) Walt van der, J. P. and Yarrow, D., Methods for isolation, maintenance, classification and identification of yeasts. In The Yeasts, A Taxonomic Study, 3rd ed., ed. by Kreger-van Rij, N. J. W., Elsevier Science Publishers B.V., Amsterdam (1984), p. 45-104.

18) Walt van der, J. P., Weijman, A. C. M., and Arx von, J. A., The anamorphic yeast genus Myxozyma gen. nov. Sydowia. Ann. Mycol. Ser. II, 34, 191-198 (1981).

19) Yamada, Y. and Aizawa, K., Electrophoretic comparison of enzymes in strains of species in the genera Myxozyma (Cryptococcaceae) and Zygozyma (Lipomycetaceae). Trans. Mycol. Soc. Jpn., 28, 163-170 (1987).

20) Yamada, Y. and Kondô, K., Significance of coenzyme Q system in yeasts and yeast-like fungi (1). Proc. 1st Special Int. Symp. Yeasts, Smolenice, p. 363-373 (1971).

21) Yamada, Y. and Kondô, K., Coenzyme Q system in the classification of the yeast genera Rhodotorula and Cryptococcus, and the yeast like genera Sporobolomyces and Rhodosporidium. J. Gen. Appl. Microbiol., 19, 59-77 (1973). 